\title{
Leituras de si: saberes docentes e história de vida de formadores de professores
}

\section{Readings oneself: teaching knowledge and life history of teacher trainers}

\author{
Leandro Passarinho Reis Júnior*
}

\begin{abstract}
RESUMO
Este ensaio trata da natureza dos saberes docentes de formadores de professores do Campus Universitário de Castanhal/UFPA por meio de histórias de vida. Objetivou-se analisar como se constituem os formadores de professores e como eles engendram e percebem a natureza e a mobilização de seus saberes docentes na prática formadora. Foram utilizadas três histórias de vida para desvelar os saberes vividos, construídos, partilhados e refletidos na docência. $\mathrm{O}$ tratamento dos episódios narrativos deu-se à luz da metodologia biográfica, utilizando-se a história de vida temática de espaços e tempos formativos, numa análise interpretativa. Os resultados apontaram que os saberes docentes fecundam e se desenvolvem na trajetória formativa do professor, abrangendo a dimensão pessoal e profissional de sua vida, compondo assim sua história numa leitura crítica de si.
\end{abstract}

Palavras-chave: Formação de professores. Saberes docentes. Histórias de vida.

\begin{abstract}
This essay deals with the nature of the teaching knowledge of teacher trainers of the University Campus of Castanhal/UFPA through life histories. The objective was to analyze how the teacher educators are constituted and how they generate and perceive the nature and mobilization of their teacher knowledge in the training practice. Three life histories were used to unveil the lived, constructed, shared and reflected knowledge in teaching. The treatment of the narrative episodes occurred in the light of the biographical methodology, using the thematic life history of spaces and formative times,
\end{abstract}

* Universidade Federal do Pará. Belém, Pará, Brasil. E-mail: 1passarinho28@gmail.com. https://orcid.org/0000-0001-9505-7808. 
in an interpretative analysis. The results showed that teacher knowledge fecundates and develops in the formative trajectory of the teacher, covering the personal and professional dimension of his life, thus composing his history in a critical reading of himself.

Keywords: Training of teachers. Knowledge teachers. Life Stories.

\section{Dos saberes da formação à formação de saberes}

Toma-se como ponto de partida a Educação, aqui compreendida como um movimento dialético, conflituoso e possível: Dialético - posto que é o início, meio e fim de qualquer aprendizagem, transformando o ser e sua vida; Conflituoso - em função de sua identidade política e ideológica, palco de disputas e pensamentos; e Possível - pois, apesar de ser um campo por vezes desvalorizado, ainda é o mecanismo pelo qual habitam opiniões, decisões e tecnologias que possibilitam a descoberta de si e do mundo em que vivemos.

Aqui, aplica-se a reflexão de Contreras (2002), para quem a educação é um fenômeno complexo, devido ser histórico, produto de trabalho dos seres humanos e, como tal, responde aos desafios que diferentes contextos políticos e sociais lhe colocam. A educação retrata e reproduz a sociedade, mas também projeta a sociedade que se quer.

Reitera-se que a Educação reflete a sociedade que temos e somos. Uma sociedade capitalista e globalizada, a qual estimula a lógica mercadológica e a formação por competências para atuação no mercado de trabalho cada vez mais competitivo e hostil. Sendo assim, ela torna-se o veículo de manutenção para as lógicas suplantadas sob a égide neoliberal, pois é por meio dela (da Educação) que projetos políticos, econômicos e sociais se materializam nos seres humanos. Essa materialização, por sua vez, perpassa valores, ideais, projetos individuais e coletivos e, sobretudo, o comportamento e as relações sociais.

Assim, ao mesmo tempo em que a educação cristaliza emoções e sentimentos capitalistas, ela também tem o poder de humanizar e possibilitar a crítica sobre a própria realidade. Por meio dela, a sociedade busca respostas para dicotomias e desafios sociais, que analisem a problemática humana desse novo milênio e, sobretudo, compreendam o papel da Educação como mecanismo de conhecimento e emancipação do indivíduo frente às provações capitalistas. Além disso, busca a minimização dos binômios bom-ruim, burro-inteligente, competente-incompetente e incluído-excluído. 
Essa é a educação possível propagada pela Pedagogia Crítica e que, segundo Sacristán (2007), é uma educação crítica e voltada para uma cultura do sujeito. Na compreensão do autor, a cultura do sujeito concebe este ser com um sujeito pensante e reflexivo de suas práticas, um sujeito do novo mundo, do mundo pós-moderno que não se contenta somente com as críticas, passa a duvidar das próprias críticas e utiliza a reflexão como investigação de suas inquietudes.

Contudo, o colapso nas concepções científicas e redefinições de saberes colocam a educação em xeque diante dos novos rumos sociais. Ao contrário do que era expurgado pela racionalidade moderna, o senso comum passa a ser sujeito e objeto de pesquisa na compreensão pós-moderna, pois, como nos ensina Santos (1987): "todo conhecimento é auto-conhecimento", e Josso (2002) complementa: "toda formação é auto-formação".

A partir dessa compreensão da formação de professores como um autoconhecimento e autoformação, começa-se a vislumbrar a complexidade que rodeia a figura do professor e os estudos apontam para uma revisão da compreensão da prática pedagógica do professor, que é tomado como mobilizador de saberes docentes.

Nessa perspectiva, amplia-se a dimensão da formação para além do ato de formar: ela assume a conotação de se formar, de se construir e se saber. Em outras palavras, ligada à subjetividade, a formação passa a configurar-se como um processo e não como um momento estanque na vida do sujeito. Sendo assim, o campo da formação de professores vislumbra-se no cenário científico, compilado com as premissas pós-modernas que preconizam a subjetividade.

\section{Trilhas da pesquisa}

Nesta empreitada, investiu-se na pesquisa biográfica, a qual utiliza histórias de vida como produção de dados para desvelar os saberes docentes, apostando nas inovações científicas e desmistificação de determinados tabus cristalizados pela ciência moderna, que impunha a dualidade sujeito $\mathrm{x}$ objeto, negava a subjetividade humana e impessoalizava a linguagem.

Nesse sentido, opta-se pelas metodologias "não convencionais" de pesquisa, que segundo André (2004), negam a neutralidade e objetividade presentes nas pesquisas ditas convencionais e que admitem o pesquisador como locutor e interlocutor. De acordo com tal perspectiva, o pesquisador interage com o pesquisado, instigando o seu "eu" e revelando o "nós", produzindo juntamente o conhecimento. 
Considera-se que as pesquisas biográficas se enquadram nas perspectivas qualitativas de pesquisa, pois também objetivam refletir e analisar a realidade complexa, em que o ser humano está inserido. Não obstante, os esforços de Pineau (1983), Ferrarotti (1988), Chené (1988), Nóvoa (1988, 1992), Josso (2002) e Dominicé (1998) contribuíram significativamente para alavancar e firmar o método (auto)biográfico como uma empreitada qualitativa de pesquisa na formação de professores.

Tais histórias foram reunidas sob a forma de biografia, mais especificamente de biografia educativa. A aproximação com fontes biográficas deve-se primeiramente ao interesse em compreender como os sujeitos compõem-se como professores em suas trajetórias de vida e percursos pessoais, familiares e sociais na arquitetura de seus saberes docentes. E, em segundo lugar, ao fato de existir - há duas décadas - um movimento internacional que aproxima as biografias com a formação de professores no campo educacional. Tal movimento visa a garantir o estatuto epistemológico das pesquisas narrativas biográficas nas pesquisas qualitativas.

Nesse sentido, o método biográfico permite que seja concedida uma atenção particular pelos processos formativos, isto é, pelos processos que as pessoas se formam. Sendo assim, reside nessa amplitude de compreensão do ser humano uma das principais qualidades que os distinguem das outras metodologias. Para Nóvoa (1988), o método biográfico dá atenção à natureza processual da formação e constitui uma abordagem que vai além da investigação e da compreensão dos processos de formação e dos subprocessos que o compõem.

Quando a vida se descortina nas narrativas orais, a pesquisa alcança o ápice das relações humanas. Thompsom (2002) ressalta "que ela lança a vida para dentro da própria história", realizando uma cooperação intelectual. E essa cooperação intelectual se ocorre à medida que o entrevistador provoca e aciona dispositivos da memória do entrevistado, que o retribui com a reconstituição de momentos, percursos, fatos e episódios significativos para a sua história de vida.

Participaram da pesquisa três formadores de professores do Campus Universitário de Castanhal/UFPA, que contribuíram com suas histórias de vida. Os critérios para a seleção dos sujeitos vincularam-se à natureza de sua disciplina pedagógica: Didática, Prática de Ensino e Fundamentos da Educação Especial.

Tais histórias foram previamente agendadas, seguindo um roteiro provocativo para a evocação das narrativas com o foco nos saberes docentes. Desse modo, utilizou-se no início de cada pesquisa um texto poético para a leitura evocativa inicial de um poeta renomado da literatura, o qual se transformou no pseudônimo de cada entrevistado: Fernando Pessoa, Clarice Lispector e Eneida de Moraes. 
Para analisar o material biográfico, as orientações de Ferraroti (1988) foram usadas, pois ele divide os materiais biográficos em dois grandes grupos: os materiais biográficos primários que correspondem às narrativas biográficas recolhidas diretamente por um investigador numa interação face a face; e os materiais biográficos secundários que correspondem aos documentos biográficos de toda a espécie que não foram diretamente recolhidos do sujeito, como, por exemplo, fotos, objetos pessoais, diários etc.

Após a coleta, os dados foram transcritos e a partir das transcrições foi possível perceber a densidade e complexidade do material colhido. As histórias traziam revelações profundas de uma leitura de si e de sua profissão. Nas leituras e releituras do material, foi um desafio para o pesquisador selecionar trechos significativos das histórias de vida para compor minha análise. Essa foi uma tarefa difícil, porque os episódios narrativos são repletos de complemento, o que torna difícil o seu recorte.

Com o término das transcrições, elas foram encaminhadas para os sujeitos da pesquisa para que conferissem o que tinham relatado e se gostariam de modificar (incluir ou excluir) trechos que considerassem íntimos e desnecessários para a pesquisa. Nesse momento, a técnica da textualização e transcrição da narrativa oral ampararou a análise, pois leva em consideração a mudança da língua da modalidade oral para a modalidade escrita, o que sugere alterações para formalizar o texto a ser estudado.

Ao final, foi possível definir cinco categorias de análise, que emergiram das histórias de vida dos sujeitos, orientadas pelos estudos de Tardif (1999), as quais foram analisadas qualitativamente.

\section{Saberes pessoais dos professores}

Compreende-se que os saberes pessoais dos professores são aqueles que se relacionam com as reminiscências familiares, com uma das primeiras fontes de saberes: a família. Aqui, incluem-se as lembranças de atores que compuseram o repertório de saberes, atores coadjuvantes que colaboraram diretamente ou indiretamente na construção da personalidade, de valores, crenças, atitudes, desejos e sonhos. Esse é o campo da Pedagogia Familiar, que diz respeito às aprendizagens desenvolvidas no seio da família e no convívio social.

Nas entrevistas e no exercício de se descrever, os professores apresentaram um pouco de seus saberes pessoais, os quais têm sua gênese nas camadas populares da sociedade e evidenciam as dificuldades vividas nos vindouros da 
década de 1960 e início da década de 1970. Nesse momento, a emoção foi mais forte. Lágrimas nos olhos, suspiros e respiração ofegante trouxeram à tona cenas de um passado difícil e digno.

[...] E depois em 70 ou 71 nós finalmente nos mudamos para Belém, que era um grande sonho fizemos a viagem de Capanema para cá num caminhão aberto com uma lona em cima misturado com todos os alimentos, com os móveis e os freios que o caminhão dava, de vez em quando nós levantávamos a lona para ver onde estávamos, foi uma mudança que foi feita à noite, foi muitíssimo divertido. E nessa mudança nós fomos morar num lugar (choro) sem as mínimas condições, de palafita e toda vez que chovia alagava, lá lembro-me de escrever com esmalte vermelho no chão de madeiras garatujas que se pareciam muito com letras do alfabeto e meus pais e irmãos aproveitavam para elogiar-me e perguntar-me o que estava escrito e eu pensava e dizia aqui está escrito papai, mamãe etc. (Clarice, Entrevista I)

[...] Eu fui para a escola com sete anos e eu fui para o Colégio São José, uma escola de elite de Castanhal como bolsista. Olha, foi impactante vestir o uniforme daquela escola e conviver de perto com pessoas que estavam distantes da nossa realidade. Mas você acaba virando um extraterrestre dentro de casa e chacota na escola. Por que assim eu não sabia me comportar naquele mundo, eu era uma menina pobre e a escola exigia muitos livros e materiais didáticos que nem sempre eu podia obter. E você ter que conviver com a sua pobreza é muito difícil. Então por muito tempo eu fui aquela menina magrinha, frágil e alvo de apelidos e eles faziam questão de me humilhar. (Eneida, Entrevista I)

[...] uma das minhas primeiras memórias que vem nesse momento, que eu odiava a escola (risos) e eu não queria ir para lá, eu não gostava da professora. Minha mãe contava que eu sentava de costas para a professora na sala de aula. Onde eu morava tinha pontes, era uma ponte de açaizeiros colados, uma ponte com tábuas que uniam açaizeiros. Nós morávamos nesse pântano no acampamento. Quando criança vivia o período das chuvas com muito entusiasmo, as casas enchiam e minha imaginação fluia em várias direções. Nós ficávamos suspensos nas redes dentro de casa, mas ao menos descuido de minha mãe lá estava eu tomando banho na água que vinha da enchente do igarapé do Galo e das águas das chuvas sem nenhum pudor ou preocupação. (Fernando, Entrevista I) 
Os registros evidenciam a dificuldade financeira das famílias que moram no interior do estado e outras que migram para a capital em busca de oportunidades. Nesse momento da entrevista, os sujeitos revisitaram suas origens nas raízes pobres da sociedade, o que pode ter sido um propulsor da transformação social que eles buscaram por meio do estudo e da educação.

Foi bonito registrar o brilho nos olhos dos entrevistados ao perceberem que buscaram uma emancipação intelectual, econômica e social, contudo, demonstram muito orgulho de destacar que fazem parte das estatísticas de pessoas que conseguiram um lugar na sociedade por meio do intelecto. Para Souza (2006), a busca de nós, na condição de seres sociais, é fortemente marcada pela dimensão cultural, no que se refere ao componente afetivo da vida e das experiências humanas. Sendo assim, a estrutura social e os grupos a quem somos vinculados constroem condições de pertença para a construção de nossos saberes sociais e identitários.

A despeito disso, Tardif (1999) acrescenta que os saberes docentes possuem sua gênese nos conhecimentos pessoais e num saber-fazer personalizado. Os saberes dos professores estão exteriores ao ofício de ensinar, pois provêm de lugares sociais anteriores à carreira propriamente dita ou situados fora do trabalho cotidiano. Isso diz respeito aos saberes pré-profissionais agregados à vida do professor, em suas vivências familiares, coletivas e sociais.

Clarice destaca o saber aprender, ou seja, sua vontade de aprender a escrever e a se expressar desde a tenra idade. Enquanto Eneida relata o saber enfrentar e superar as dificuldades da vida, os preconceitos vividos na escola precocemente e os complexos absorvidos por experiências negativas, destrutivas. Fernando, por sua vez, conta as dificuldades com a escola e o saber resistir aos dissabores da vida e, ao mesmo tempo, ele também apresenta o saber voltado para a ludicidade das crianças que vivem em condições precárias, em bairros periféricos que aprendem a divertir-se com a realidade que se apresenta para elas. Esses excertos evidenciam um saber, inclusive um dos saberes mais ricos da infância.

\section{Saberes da formação escolar}

Esses são as reminiscências da escola e as aprendizagens para além das salas de aula. É um momento muito rico para a formação humana e social, dado o seu tempo. É um turbilhão de saberes construídos e partilhados no espaço escolar. É uma vida que passamos na escola, construída com o conhecimento de pessoas, com as descobertas e redescobertas, com os sonhos fecundados etc. 
No que tange ao desejo de aprender e às lembranças do ensino primário, os relatos revelam que:

[...] no primário tive boas professoras que me estimulavam a escrever longas histórias, fazia longas descrições de fatos. Acho que elas pensavam que eu queria ser uma escritora, mas tornei-me assídua nas leituras e nessa época comecei a ler os clássicos da literatura brasileira como Machado de Assis e José de Alencar, lia sem compreender muito bem, mas adorava acompanhar o enredo dos livros. Também comecei a tomar gosto pela Matemática, achava uma brincadeira desvendar a resposta de um problema, parecia um quebra-cabeça. Pegava livros e fazia sozinha dezena de cálculos e era uma vitória acertá-los ao máximo. [...] as professoras me ajudaram muito, mas aquilo que era dado na escola não era suficiente para a minha curiosidade e o desejo que tinha em aprender. Infelizmente em minha casa haviam poucos livros e quando não tinha opção partia até para as listas telefônicas(risos) um exagero confesso. Mas era o meu sentimento e o meu desejo na época... de aprender o máximo possivel. (Clarice, Entrevista I)

[...] eu descobri que podia superar a minha pobreza e desvantagem econômica em relação aos meus amigos por meio do estudo e não foi por que eu quis não. Como eu era bolsista eu não podia tirar menos de sete nas provas senão geraria a perda da bolsa de estudos, então eu descobri que eu podia estudar muito e tirar notas altas. Então eu acabei me transformando na "menina dos olhos" dos professores. Eu me matava! Desde muito cedo eu assumi um compromisso absurdamente... e eu paguei um preço muito alto na minha vida. Ter que peitar aquelas pessoas que estavam me testando sempre. [...] só que por outro lado uma coisa muito legal aconteceu: eи descobri que eи era forte, que eи podia me matar de estudar (risos) e ser sempre elogiada, condecorada e era legal ganhar medalhas e eu sempre ganhava medalha de ouro e assim eu descobri que isso podia ser a tônica da minha vida. Eu ganhei o amor e o carinho dos professores e é muito legal quando você é muito estudioso e alguém reconhece. (Eneida, Entrevista I)

[...] quando eu fui cursar a primeira à quarta série a escola era. Era uma escola que eu tinha que andar muito e as minhas pernas eram muito curtas com certeza. Eu ia para a escola por baixo do sol no horário de uma hora da tarde. Eu ia com tanta raiva para a escola no periodo da tarde, mas eu gostava da volta no final da tarde, gostava de ser confundido com os 
adultos que voltavam do trabalho e os alunos noturnos (risos). Eu não gostava de ficar sentado, eu sempre gostei dos meus professores mesmo os que me reprovavam. Gostava do lugar importante que eles ocupavam. Queria falar de outros assuntos na escola, perguntar sobre outras coisas, nunca deixavam. A escola para mim era o lugar para escrever, eu tinha que escrever muito, minhas mãos doiam [...] mas, eu gostava mesmo era de sair, ir embora pra casa quando estava chovendo. Eu gostava de chegar molhado em casa, acreditava que minha mãe tinha pena de mim, creio que eu desejava adoecer para ouvir coisas do tipo: "ele foi para a escola e veio na chuva, coitado adoeceu de tanto estudar". No trajeto eu pensava que as pessoas me olhavam como aquele exemplo de estudante que mesmo debaixo de chuva não deixava de ir para a escola e isso alimentava muito no meu imaginário, na minha fantasia de que eu era um bom estudante. (Fernando, Entrevista I)

Os excertos demonstram o desejo de aprender a ler e a escrever, suscitados por Clarice que utilizava até as listas telefônicas para satisfazer. O poder de superação pelo estudo desenvolvido por Eneida, ao ser menosprezada por seus colegas de classe e até por professores, por pertencer à classe pobre e ser bolsista numa escola tradicional particular. E o carinho que Fernando tinha pelos seus professores, apesar de explicitar seu ódio pela escola e por frequentar as aulas, ele relata que gostava até daqueles que o reprovavam.

Essas pistas dão uma compreensão de como os saberes docentes são alimentados pelas experiências vividas. Assim, quando se enfrenta desafios e se ultrapassa os obstáculos da vida, aprende-se muito sobre si mesmo, sobre a força que move as pessoas a buscarem o saber, inclusive o saber de si. E a escola é o espaço de excelência para a descoberta de saberes, posto que é nela que se entra em contato com as experiências cognitivas e sociais.

Segundo Souza (2006), o conhecimento de si, expresso nas trajetórias de escolarização, implica dimensões formativas e autoformativas, bem como revela aprendizagens experienciais e potencializa formas de compreensão da cultura escolar e dos rituais engendrados no seu cotidiano.

\section{Saberes da formação acadêmica}

Esses relacionam-se aos saberes provenientes das instituições formadoras de professores. Esses saberes provêm de aulas, estágios, seminários, palestras, oficinas, ou seja, do contato com a rotina acadêmica. 
A fim de compreender melhor a formação acadêmica dos sujeitos, vale esclarecer que todos cursaram a Universidade Federal do Pará praticamente no mesmo período: Clarice (Pedagogia: 1988-1992), Eneida (Pedagogia: 19871992) e Fernando (Psicologia: 1986-1996). Dessa forma, viveram descobertas e rupturas científicas daquele momento histórico.

Em relação ao ingresso na academia e no ensino superior, as escolhas foram influenciadas pelos valores culturais da sociedade e do desejo em emergir social, cultural e economicamente. Sendo assim, os entrevistados evidenciam que:

[...] no segundo grau eu já estava satisfeita com a Contabilidade e isso já não me apetecia mais (risos) e eu queria partir para uma coisa diferente. Então eu já queria Psicologia por que eu achava o nome bonito "Psicologia" e uma vez eu fui ao ônibus e uma moça dizia que os melhores cursos eram Psicologia e Pedagogia, porque Pedagogia ganha um dinheirinho e ela fez um gesto com os dedos de "dinheirinho". Ai eu pensei: não é que poderia ser? Ai a minha tia me incentivou: minha filha faça Pedagogia. Ela também tinha feito Pedagogia e se aposentou com várias gratificações que acumulou do salário dela da Seduc. Naquela época saiu uma lista dos marajás do Pará e o nome dela estava lá, o que veio confirmar o que a moça falou dentro do ônibus que um Pedagogo ganhava bem. (Clarice, Entrevista II)

[...] quando eu terminei o Magistério eu me casei e fui morar fora do Pará, em Tabatinga/AM. Lá eu vivi muitas dificuldades foi outra história, outro aprendizado e ai a gente voltou para Castanhal. Nesse momento eu fiz todos os concursos para professora, fui aprovada e tinha decidido que ia fazer a universidade. Ai eu fui para o cursinho e duas pessoas me impulsionaram muito pra isso e uma em especial - a minha sogra. Uma mulher independente que trabalhava e estudava. Então quando teve o vestibular intervalar em Pedagogia em 1987 eu fiz. Meu filho era pequenino, tinha apenas dois anos e todo mundo dizia "Tu és louca! Trabalhas de manhã e de tarde! Que horas tu vais estudar?!". Quando saiu o bendito listão eu tinha passado (risos). (Eneida, Entrevista I)

[...] eu vivia o movimento cultural da época, um movimento social efervescente que aproximava da música popular brasileira, comecei a ler contos de Clarice Lispector influenciados pela minha amiga hare krishna (risos) e me aproximei do pessoal do teatro. Tentei participar do coral da Escola Técnica e não consegui. Me apaixonei pelo canto e me 
divertia cantando nos bares da cidade com um grupo de amigos do Souza Franco, não como cantor profissional, mas para ser ouvido, ensurdecer o tempo e o ouvido das pessoas. Nessa época eu me preparava para fazer vestibular para a área de exatas. Fiz dois anos para Engenharia Civil e não fui aprovado. Nesse momento eu me aproximei da Cruz Vermelha e esse contato com uma entidade filantrópica me fez pensar pela primeira vez em prestar vestibular para as Ciências Humanas. Fiz vestibular em 1985 para Serviço Social no Cesep hoje Unama, Psicologia no Moderno e Psicologia na UFPA. Passei nas três, mas eu queria a UFPA. (Fernando, Entrevista I)

Na narrativa de Eneida está clara a influência da formação inicial em Magistério na Escola Normal e o fato dela exercer a função de professora, o que a levou a optar pela área de educação, pelo curso de Pedagogia. Todavia, os excertos de Clarice e Fernando denotam a influência do meio social no qual estavam inseridos. Ela por ter uma pessoa da família que era pedagoga bem-sucedida, e ele por envolver-se no movimento social e ali ter despertado o interesse pelas ciências do humano. Segundo Souza (2006), a memória e a história de cada sujeito revelam "experiências formadoras" empreendidas nos tempos e espaços de convivência, seja na família e nas mais diferentes convivências na itinerância de vida.

Esses espaços formativos revelam os saberes que a sociedade elege como promissor ou não. No caso da educação, o saber sempre esteve relacionado à possibilidade imediata de trabalho, mesmo desvalorizado. Outra regularidade que desponta na análise é o fato dos entrevistados terem cursado a mesma universidade, no mesmo tempo histórico, porém em espaços distintos. Isso pode levar a conclusão de que eles enfrentaram os mesmos pressupostos de formação, embora em cursos diferenciados. Segundo eles:

[...] as primeiras aulas foram desastrosas e eu não consegui compreender as aulas e os discursos eram escutados por mim de forma absoluta e distante da minha realidade, ao mesmo tempo em que vivi momentos históricos importantes para a minha formação como a luta pela meia passagem e o engajamento no movimento estudantil. Nas aulas eu escutava tudo de forma absoluta e eu não conseguia relativizar nada. Quando eu ouvi pela primeira vez o conceito de subjetividade capitalista eu me lembro "Meu Deus o que é isso?!" foi o primeiro conceito que pirou a minha cabeça em uma disciplina chamada Psicologia Social I. Eu era uma pessoa muito querida no curso de Psicologia, os professores 
gostavam de mim e eu não entendia por quê, porque eu não era um aluno exemplar. Algumas vezes eu perguntava algumas coisas que eu queria saber e talvez isso me deixava muito inquieto e as turmas eram muito caladas e eu perguntava tudo. (Fernando, Entrevista I)

[...] quando começou o intervalar eu não tinha muita noção do que era o curso de Pedagogia não. As primeiras etapas com disciplinas de trezentas horas de Filosofia I, II e III, Sociologia I, II e III, Psicologia I, II e III. Quando aquilo começou, olha tudo ficou dificil. Eu sempre tive muita disciplina para estudar, isso é verdade. Mas, lá era outro mundo, outra história e assim, a ideia que eu tinha de universidade também era outra. Na primeira etapa era uma loucura, estudar oito horas sem parar è noite fazer os trabalhos na casa das colegas era barra. Eu abandonava o meu filho e marido em função dessa história de estudar. Teve muito conflito. E tem mais: nós estudávamos nas "férias" e quando terminava o módulo nós caíamos de paraquedas dentro da sala de aula, então era uma rotina de etapas de 450 horas, com seis disciplinas e logo em seguida a gente caia dentro das salas de aula do Estado e duzentas de município (risos). Não me pergunte como! Mas eu fazia isso (risos). (Eneida, Entrevista I)

[...] quando eu me deparei com Introdução à Educação e aí veio o Paulo Freire, a partir dele eu disse: é isso mesmo que eu quero! Eu tive um professor excelente de Ciência Politica que eu admirava, era um alemão recém-doutor e ai ele me apresentou os clássicos da Sociologia como Maquiavel, o Marx, Gramsci. Nessa época ele já fazia uma crítica muito forte ao marxismo e eu fui particularmente influenciada por esta crítica. Ai, isso me influenciando para que eu estudasse muito Sociologia. Então eu comecei a ler o Habermas, o Rousseau e descubro que tem a obra "Emílio" na educação. E também descubro que as disciplinas que o curso de Pedagogia vai te dar, naquela época a carga horária de 90 horas e você fazia, por exemplo, Introdução à Filosofia I, II e III, depois História, a mesma coisa Sociologia. Então o que foi que aconteceu: eu vi que o curso de Pedagogia ia me dá aquilo que eu queria, que era estudar os clássicos e ao mesmo tempo relacionando-os à educação, era um casamento perfeito. (Clarice, Entrevista II)

$\mathrm{Na}$ formação acadêmica, destacam-se os saberes curriculares e disciplinares provenientes das disciplinas e conteúdos dos cursos de formação. E os registros evidenciam bem o choque causado pelos primeiros contatos com o conhecimento científico e os saberes que dele surge. 
Apesar de hoje se ter uma visão ampliada da dimensão dos saberes docentes, isto é, de que eles não estão unicamente voltados para os conteúdos e disciplinas, não se pode esquecê-los, pois eles fundamentam a prática docente e vinculam-se às pesquisas e práticas. É por meio dos conhecimentos disciplinares que se compreende a área de atuação e sua complexidade. E no caso dos formadores de professores, eles atrelam-se a uma matéria vinculada a várias disciplinas, isto é, aproximam-se de uma área específica da educação.

Vale ressaltar que essas disciplinas, conteúdos e conhecimentos são transmitidos por professores que passam e marcam a formação: inclusive, é possível dizer que quem promove a aproximação de conteúdos e disciplinas são os professores e suas metodologias de ensino. E os depoentes citaram os professores que contribuíram para sua formação e atração pela rotina acadêmica.

\section{Vidas que contam os saberes docentes}

$\mathrm{Na}$ produção dos dados, tentou-se compreender alguns dos contornos traçados nas tramas formativas dos professores, buscando entender as significações que eles atribuem aos seus saberes docentes. Encarou-se esse esforço intelectual como uma busca da compreensão dos professores a partir dos saberes aprendidos na/para/com a profissão de formador de professores.

Por meio das narrativas biográficas, foi possível desvelar o ser que é o professor e seus saberes da docência. Contudo, conforme Souza (2006), a narrativa biográfica oferece um terreno de implicação e compreensão dos modos como se concebe o passado, o presente e, de forma singular, as dimensões da memória educativa, isto é, dos processos de formação.

Nesse exercício narrativo, os professores-formadores fizeram uma leitura de si por meio de "lembranças definidoras da rememoração, permitindo compreender os tempos e espaços da formação" (MIGNOT, 2003, p. 136). Assim, os sujeitos narraram suas histórias de vida propiciando compreender modos particulares de compreender o peso do desafio de ser formadores de professores e de construir em si e nos outros os saberes docentes.

Inicialmente, buscou-se identificar o que os professores-formadores sabem e pensam sobre os saberes docentes. Nesse sentido, eles destacaram que:

[...] são saberes plurais, complexos e advindos essencialmente da experiência de vida do professor. Mas acredito que ele seja uma somatória 
de todos os conhecimentos agregados da vida, da nossa formação de professores. (Clarice, Entrevista II)

[...] são conhecimentos construídos no exercício da docência ao longo da história de vida e na labuta da educação, seja como educador, gestor, coordenador, supervisor, em espaços escolares ou não, nos movimentos sindicais, em eventos, no ensino, na pesquisa, na extensão e principalmente na relação com os outros sujeitos da educação. (Eneida, Entrevista II)

[...] os saberes docentes são articulações que construímos e articulamos durante nossas práticas profissionais reflexivas, seja na nossa sala de aula, seja nas reuniões de classe, seja nos grupos de estudo. Eles também se expressam nos diálogos cotidianos com nossos familiares, amigos. (Fernando, Entrevista III)

Como se pode perceber, é consenso para os formadores que os saberes docentes são construídos e articulados na vida e na formação de professor. Para eles, tais saberes são complexos e surgem de diversas inter-relações sociais, humanas e pedagógicas, o que corrobora a tese de Tardif (1999), que expressa que os saberes docentes são saberes plurais, complexos e heterogêneos, formados pelo amálgama de saberes oriundos da formação profissional e de saberes disciplinares, curriculares e experienciais.

Contudo, existem aspectos a serem evidenciados nos excertos acima. Em sua fala, Clarice destaca que os saberes docentes provêm da experiência, mas não somente dela. Em outras palavras, os saberes docentes são conhecimentos oriundos da vida e da itinerância dos professores.

Entretanto, a formação do professor é impulsionada pelos saberes docentes e vice-versa. Assim, ao se formar, o professor forma saberes sobre sua vida e profissão, os quais serão mobilizados na prática profissional, no saber-fazer. Para Tardif (1999, p. 102): “os saberes docentes fecundam-se na vida do professor e nela se desenvolvem".

No excerto de Eneida, há uma compreensão de saberes docentes para além da atividade docente de sala de aula. Ela destaca outras dimensões pedagógicas que exigem competências sociais e humanas, como eventos e atividades de pesquisa.

Fernando, por sua vez, traz uma visão de saberes que ultrapassa o lócus da docência e se aproxima da reflexão. Ele compreende os saberes docentes como 
conhecimentos, competências e, sobretudo, atitudes reflexivas que contribuem para a materialização de práticas educativas. Nessa perspectiva, evidencia-se o caráter humano do trabalho docente que carrega as marcas do ser humano (TARDIF, 1999).

A partir das definições dos interlocutores da pesquisa e pela literatura acerca dos saberes docentes, é possível demarcar a definição acerca da temática, visto que os saberes docentes são um conjunto de conhecimentos, competências e atitudes engendradas na vida e na profissão professor. Tais saberes, por conseguinte, são peças que montam o quebra-cabeça complexo e inconcluso que é o professor. Sendo assim, eles configuram-se como um tesouro depositado no professor, na sua essência, o qual ninguém é capaz de extrair, tirar ou furtar.

\section{A interseção de saberes}

Parte-se do princípio de que os saberes docentes não são compartimentalizados, ao contrário, são inter-relacionados na vida e na prática docente. Sendo assim, ao compor as histórias de vida, houve uma explosão de informações, conhecimentos e experiências que deram indícios da riqueza do método biográfico, bem como da dificuldade de o sistematizar.

Nesse sentido, as categorias propostas por Tardif transformaram-se num caleidoscópio à medida que os saberes (pessoais, da escola, da formação, da experiência e profissionais) se entrecruzavam nas narrativas, nas continuidades e descontinuidades históricas. Dessa forma, as histórias aproximavam-se a partir do tempo histórico vivido dos sujeitos e se distanciavam dela na forma/modo como cada um subjetivou a sua itinerância formativa.

Conforme Bolívar (2002), narrar uma história de nossa vida é uma autointerpretação do que somos, é uma leitura crítica de si. É uma autoinvenção, descrição e reflexão do seu eu, é um exercício introspectivo, emotivo e aprendiz. Nesse exercício formativo de colher as histórias de vida, houve aspectos evidenciados pelos interlocutores que vale a pena apontar.

Eles destacaram, juntamente à experiência profissional, a importância da formação continuada para o entendimento cada vez melhor de seus próprios saberes e sobre a responsabilidade de formar professores. Para eles, ser professor é uma busca inconclusiva e deter os saberes docentes é uma tarefa reflexiva, é uma comunhão que exige autonomia e humildade intelectual.

Por conseguinte, os informantes ressaltaram episódios significativos de suas histórias de vida e para cada momento eles refletiam sobre os saberes 
apreendidos em cada etapa de formação e de vida. Assim, foi salutar rememorar junto a eles passagens históricas, sonhos estudantis e convicções profissionais, pois isso possibilita conhecer mais o professor, seus pensamentos e saberes.

\section{Considerações finais}

Mergulhar nos saberes docentes foi um exercício subliminar e desafiador. Por meio das narrativas, é possível compreender e constatar que um professor não se forma de uma hora para outra em universidades, a formação é um contínuo, é uma arquitetura inacabada do ser. Rememorar com os formadores de professores a história da educação, os paradigmas de formação de professores, bem como as trajetórias significativas de ser um professor de seu tempo é um exercício de reconstrução do passado e projeção do futuro a partir de seus saberes docentes.

Ouvir uma polifonia de vozes, discursos, elucubrações, reflexões e aprendizagem nas entrevistas corrobora o quanto os sujeitos aprenderam mais de si e de suas escolhas, leram seus desejos, frustrações e alegrias. E esses discursos e narrativas estavam prenhes de saberes de si, da vida e de sua profissão.

Conclui-se que os entrevistados conhecem seus saberes e percebem a emergência e a importância desse campo de estudo na formação de professores. Entretanto, percebe-se que há muito a se aprender sobre a totalidade de saberes docentes concernentes aos professores em suas ações pedagógicas. E essa é uma caminhada permanente, que obriga o olhar a refletir para si e para os saberes que permeiam sua profissão.

Todavia essa não é uma tarefa fácil e as leituras de si não param por aqui, elas apenas começam, pois ainda há muitos retoques a fazer sobre a gama de saberes embutidos no professor-formador. Contudo, as construções das análises possibilitaram entender que os saberes docentes são muito mais amplos do que se imagina: eles são a própria essência.

Finalmente, compreende-se que os saberes são as correntes que formam o elo da formação, que não se separam e nem se quebram, ao contrário, fortalecem-se cada vez mais, com a própria vida. E mesmo diante de crises profissionais, os professores formadores reencantam seu olhar para a docência, reafirmam seu papel social, deslumbram-se com seus saberes e projetam ideologias e sonhos de uma formação mais ética, crítica e reflexiva a partir desse exercício colaborativo de suas leituras de si. 


\section{REFERÊNCIAS}

ANDRÉ, Marli. Metodologias não-convencionais em teses acadêmicas. In: FAZENDA, Ivani (Org.). Novos enfoques da pesquisa educacional. 5. ed. São Paulo: Cortez, 2004.

BOLÍVAR, Antônio. Profissão professor: o itinerário profissional e a construção da escola. Bauru, SP: Edusc, 2002.

CHENÉ, Adèle. A narrativa de formação e a formação de professores. In: NÓVOA, António; FINGER, Matthias (Org.). O método (auto)biográfico e a formação. Lisboa: Ministério da Saúde, 1988.

CONTRERAS, José. Autonomia de professores. São Paulo: Cortez, 2002.

DOMINICÉ, Pierre. O processo de formação e alguns dos seus componentes relacionais. In: NÓVOA, António; FINGER, Matthias (Orgs.). O método (auto)biográfico e a formação. Lisboa: Ministério da Saúde. Depart. de Recursos Humanos da Saúde/Centro de Formação e Aperfeiçoamento Profissional, 1988. p. 51-61.

FERRAROTTI, Franco. Sobre a autonomia do método biográfico. In: NÓVOA, António; FINGER, Matthias (Orgs.). O método (auto)biográfico e a formação. Lisboa: Ministério da Saúde. Depart. de Recursos Humanos da Saúde/Centro de Formação e Aperfeiçoamento Profissional, 1988. p. 17-34.

JOSSO, Marie-Christine. Experiências de vida e formação. São Paulo: Cortez, 2002.

MIGNOT, Ana Christina Venâncio. Práticas de memória docente. São Paulo: Cortez, 2003.

NÓVOA, António; FINGER, Mathias (Org.). O método (auto)biográfico e a formação. Lisboa: MS/DRHSCFAP, 1988.

NÓVOA, António. Os professores e as histórias da sua vida. In: NÓVOA, António (Org.). Vidas de professores. Porto: Porto Editora, 1992.

PINEAU, Gaston. Produire sa vie: Produire sa vie autoformation et autobiographie. Paris: Edilig; Montréal: St. Martin, 1983.

SACRISTÁN, José Gimeno. A educação que ainda é possivel: ensaios sobre uma cultura para a educação. Porto Alegre: Artmed, 2007.

SANTOS. Boaventura de Sousa. Um discurso sobre as ciências. Porto: Afrontamento, 1987.

SOUZA, Elizeu Clementino de. O conhecimento de si: estágio e narrativas de formação de professores. Rio de Janeiro: DP\&A; Salvador, BA: UNEB, 2006.

TARDIF, Maurice. Saberes docentes e formação profissional. 4. ed. São Paulo: Vozes, 1999. 
REIS JR., L. P. Leituras de si: saberes docentes e história de vida de formadores de professores

THOMPSON, Paul. A voz do passado: história oral. 3. ed. São Paulo: Paz e Terra, 2002.

Texto recebido em 27 de outubro de 2018 .

Texto aprovado em 30 de janeiro de 2019. 